\title{
Grindelia squarrosa in Ukraine: current distribution and ecological and coenotic peculiarities
}

\author{
Vira V. Protopopova ${ }^{1,2} \mathbb{1 D}^{\text {, }}$, Yakiv P. Didukh ${ }^{1}$ (D) Vasyl S. Tkachenko ${ }^{1}$, \\ Myroslav V. Shevera ${ }^{2,1}$ (1) , Oksana O. Kucher ${ }^{1}$ (i), Liudmyla V. Zavialova' ${ }^{1}$ (i) \\ \& Anton P. Biatov ${ }^{3}$
}

Key words: Grindelia squarrosa, introduction, invasive species, natural habitat, naturalization.

Ključne besede: Grindelia squarrosa, introdukcija, invazivne vrste, naravni habitat, naturalizacija.
Received: 15. 9. 2020

Revision received: 31.3 .2021

Accepted: 15. 4. 2021

\begin{abstract}
Grindelia squarrosa (Pursh) Dunal. (Asteraceae) is a species with high invasiveness capacity in Ukraine, especially in the Steppe zone. The first data on the finding of escaped plants in Europe were recorded in the 40's of the last century. There were three naturalization centres in Ukraine, from where the species began to spread. In the secondary range in Ukraine, G. squarrosa is characterized by high levels of seed productivity and germination, variable modes of dispersal, wide ecological and coenotic amplitudes and CSR-strategy. The trend continues with the spread of the species in western, north-western and northern directions, and today more than 300 localities confirming this trend are already known. In the past 20 years, 92 new localities have been recorded. G. squarrosa is a transformer, widespread in the southern regions of the Steppe zone. As a result, new plant communities are formed. In general, this species is recorded in communities of five vegetation classes. In terms of ecological indicators, the optimum of the species is in the Steppe zone. It can be predicted that, due to the potential ability of the species to adapt and under the influence of climatic change, there is a higher probability that the species will spread in the future in northern and western directions. The condition for such an expansion is disturbance of meadow-steppe fringe xeromesic communities, with decreased coenotic competition.
\end{abstract}

\section{Izvleček}

Grindelia squarrosa (Pursh) Dunal. (Asteraceae) je ena izmed zelo invazivnih vrst v flori Ukrajine, še posebej v njeni stepski coni. Prvi podatki o nahajališčih vrste v naravi v Evropi so iz štiridesetih let prejšnjega stoletja. V Ukrajini se je vrsta razširila iz treh centrov. V sekundarnem arealu v Ukrajini ima vrsta $G$. squarrosa visoko produkcijo semen in kaljivost, zanjo so značilni različni načini razširjanja, široki ekološka in združbena amplituda ter CSR strategija. Trend se nadaljuje s širjenjem vrste na zahod in sever in znanih je več kot 300 lokacij, samo v zadnjih 20 letih je bilo zabeleženih 92 novih. G. squarrosa je preoblikovalec (transformer) in splošno razširjena vrsta v južnih predelih stepske cone. Posledica širjenja je tudi pojavljanje novih rastlinskih združb. V splošnem se vrsta pojavlja v združbah iz petih razredov. Ekološki pokazatelji kažejo, da ima vrsta optimum v stepski coni. V prihodnje lahko pričakujemo verjetnost širjenja vrste proti severu in zahodu zaradi sposobnosti prilagajanja in vpliva klimatskih sprememb. Pogoj za tako širjenje pa so tudi motnje v travniško stepskih kseromezofilnih združbah z zmanjšano kompeticijo.

\footnotetext{
1 M.G. Kholodny Institute of Botany, NAS of Ukraine, Tereschenkivska St. 2, Kyiv, 01004 Ukraine.

2 Ferenc Rákóczi II Transcarpathian Hungarian Institute, Koshut Sq. 6, Berehovo, 90200 Ukraine.

3 Slobozhanskyi National Nature Park, st. Zarichna, 15, Krasnokutsk, Kharkiv region, Ukraine.

* Corresponding author: E-mail: kucher.oksana29@gmail.com
} 


\section{Introduction}

By the end of the $20^{\text {th }}$ century, invasions of non-native species were widely recognized as one of the major threats to biodiversity on a global scale. In accordance with the requirements of the Global and European Strategy for the Control of Invasion Species, a comprehensive study of the causes and peculiarities of invasive species distribution is one of the priorities in solving problems of phyto-invasion prevention and control.

Curlycup gumweed (Grindelia squarrosa (Pursh) Dunal., Asteraceae), is a species with high invasiveness capacity in Ukraine, especially in the Steppe zone (Protopopova et al. 2002, Kucher 2012, Protopopova \& Shevera 2019).

The species is of North American origin. Its natural range extends from the southern areas of Manitoba to Texas and eastwards to Idaho and Arizona. It is also naturalized in the US eastern states (Gleason \& Cronquist 1991). The species is fairly polymorphic in North America and includes four varieties: G. squarrosa var. squarrosa, G. squarrosa var. nuda (Wood) Gray, G. squarrosa var. quasiperennis Lunnell and G. squarrosa var. serrulata (Rydb) Steyerm. The species hybridizes with $G$. arizonica (Bartoli \& Tortosa 2012).

There are 44 species in the genus Grindelia Willd (Steyermark 1937), but only G. squarrosa has spread to almost all continents. In its natural range, G. squarrosa is a dwarf subshrub (chamaephyte). In terms of water regime, it is a xeromesophyte and in terms of light, it is a heliophyte (Strother \& Wetter 2006). The plant is known as ornamental, medicinal and technical (Steyermark 1937, Neupane 2017). Plants are mainly confined to dry places and mostly distributed in dry prairies, but also occur on moist soils in areas with disturbed vegetation. The species grows well on sandy, loamy, clay loamy and gravelly soils, and even on gravel, clay and dense clay. In its native range, G. squarrosa has been recorded in many habitat types: deciduous (oak, elm-poplar) and coniferous (fir and pine) forests, shrubs, prairies etc. (Peterson 1970). It develops in anthropogenically transformed habitats: railway roadsides, depleted pastures and arable lands, often forming an almost monodominant community. The species has high resistance to unfavourable environmental conditions. G. squarrosais is therefore used, for example, for restoration of disturbed lands in south-eastern Montana and of roadside areas in southern Wisconsin (Sieg et al. 1983). So, within its natural area, the species is characterized by a wide ecological amplitude and high capacity for habitat development; i.e., the ability to expand its ecological niche, which is actually realized in geographical and ecological terms.
In 1804, G. squarrosa, named Aster spathulatus Hort., was introduced to Europe for the first time in the Royal Botanical Gardens of Madrid (Spain) (Steyermark 1937, Neupane 2017) as a medicinal and ornamental plant. In the nineteenth and early twentieth centuries, the plant was already cultivated in many botanical gardens in $\mathrm{Eu}-$ rope: Montpellier, Berlin, Kew (Steyermark 1937), and also in northern Europe (Finland and Sweden) (Karlsson 1998, Kurtto, 2020). Botanical gardens were obviously one of the centres from which this plant began to spread into natural habitats, although there were also other ways (Greuter 2005-2007, DAISIE 2009).

The first data on the finding of wild plants in Europe were recorded from the 40's of the last century: Lithuania in 1946 (Natkevičaite 1951, Gudžinskas 1997) and Ukraine in 1949 (Bilyk 1950), later - Moldova in 1958 (Myrza et al. 1987), Latvia in 1960 (Flora of the Baltic Republics 2003). The next record of the species is from the North Caucasus in 1984 (Ignatov \& Makarov 1984), Udmurtia (Puzyrev 1985), in many regions of the European part of Russia (Flora ... 1994), in the Far East (Kozhevnikov \& Kozhevnikova 2007), Belarus in 1986 (Tretyakov 1990), Slovakia in 1992 (Jehlik et al. 2013), Romania in 1998 (Anastasiu \& Negrean, 2005, Sîrbu \& Oprea 2008, Truta et al. 2012), Estonia in 1999 (Kukk 1999), Ireland in 2002 (Reynolds 2002), Belgium in 2005 (Verloove 2006), Hungary in 2004 (Balogh et al. 2004, Botta-Dukát 2008), Bulgaria in 2009 (Vladimirov \& Petrova 2012), Georgia in 2013 (Jinjolia \& Shakarishvili 2014) and Armenia in 2016 (Gabrielian et al. 2016). Distribution centres of this species are also found outside the Holarctis, in South America and Australia (Hansen 1976).

The species is mainly confined to secondary anthropogenic habitats (railway embankments, roadsides, windbreaks, pastures, quarries, ruderal sites, urban wastelands, mostly sandy, steppe fallows, clay and sandy riverbanks, rocky scree etc.). The species is distributed in semi-natural and natural habitats with reduced coenotic competition (degraded sandy steppe, woody grasslands and forest fringes, steppe slopes, sands and granite outcrops) (Protopopova et al. 2009, Shevera et al. 2019).

In Ukraine, in particular, rapid expansion of the species and invasion into different coenoses have been observed. Information on the current distribution of the species is significantly different from the previously published data (Protopopova 1973, 1991, Protopopova \& Tkachenko 1979). The same concerns the information on its inclusion in different plant communities (Solomakha et al. 1992). The purpose of our study was thus to summarize the current distribution of the species in Ukraine, including time stages of distribution, and to identify its ecological and coenotic characteristics. 


\section{Materials and methods}

The G. squarrosa study is based on critical analysis of herbarium data, literary sources and the data of field studies of the authors. We analysed the following herbarium collections: Herbarium of M. G. Kholodny Institute of Botany, NAS of Ukraine $(K W)$, Herbarium of M. M. Grysko National Botanical Garden, NAS of Ukraine (KWHA), Herbarium of Donetsk Botanical Garden, NAS of Ukraine (DNZ), Herbarium of Kryvyi Rih Botanical Garden, NAS of Ukraine (KRW), Herbarium of the Institute of Ecology of the Carpathians, NAS of Ukraine (LWKS), Herbarium of Yu. Fedkovych Chernivtsi State University (CHER), Herbarium of Taras Shevchenko National University of Kyiv (KWU), Herbarium of I. I. Mechnikov Odesa National University (MSUD), Herbarium of Oles Honchar Dnipro National University $(D S U)$, Herbarium of V. N. Karazin Kharkiv National University ( $C W U$ ), Herbarium of Kherson State University $(K H E R)$, Herbarium of the Academy of Bioresources and Life Management, Crimean Agro-Technological University (CSAU), V. I. Vernadsky Taurian National University (SIMF), Herbarium of the State Nikita Botanical Garden - National Scientific Center, NAAS of Ukraine (YALT), Herbarium of Volodymyr Vynnychenko Central Ukrainian State Pedagogical University (Kropyvnytskyi) and the Herbarium of V. G. Korolenko Poltava National Pedagogical University ( $P W U$ ).

The G. squarrosa distribution map, based on the herbarium data and locations identified in the relevés, was designed in MapInfo Professional Version 7.0 software.

Relevés with the presence of the species were made by the authors according to the standard method. The plot size was $10 \mathrm{~m}^{2}$, species cover was recorded in percentage form. In total, 134 relevés were used for the analysis: 6 unpublished, provided by I. I. Chorney and A. I. Tokaryuk, as well as 6 relevés by Ye. V. Polyovyj (Polyovyj 2013), 75 relevés from the publication of M. G. Smetana (Smetana 2000) and D. S. Vynokurov (Vynokurov 2014).

Ecological analysis was carried out according to the phytoindication method (Didukh \& Pluta 1994) on the basis of ecological scales proposed by Didukh (2011). They are characterised by the following dimensions: soil humidity ( $\mathrm{Hd}-23$ grades), variability of damping ( $\mathrm{fH}-$ 11 grades), soil acidity ( $\mathrm{Rc}-15$ grades), total salt regime (Sl -19 grades), carbonate content $(\mathrm{Ca}-13$ grades), nitrogen content ( $\mathrm{Nt}-11$ grades), aeration of the soil (Ae -15 grades), thermoregime of the climate $(\mathrm{Tm}-17$ grades), humidity of the climate (Om -23 grades), continentality of the climate ( $\mathrm{Kn}-17$ grades), cryoregime of the climate ( $\mathrm{Cr}-15$ grades) and lightness in the community (Lc -9 grades).
The calculation of ecological values was made using JUICE 7.0 (Tichy 2002). To visualise the multivariate floristic similarity patterns, we carried out Detrended Correspondence Analysis (DCA). In the ordination diagram, environmental factors and vegetation parameters correlated to one of the axes with $r^{2} \geq 0.20$ were displayed as vectors.

To compare environmental factors and their interdependence, we built a dendrogram based on the averaged indexes of 12 environmental factors (Didukh's scales) calculated for each cluster using STATISTICA 10.0. Syntaxonomy is in accordance with Mucina et al. (2016) indicating the associations of Prodrome of the vegetation of Ukraine (2019).

\section{Results and discussion}

\section{Historical and current distribution data of G. squarrosa in Ukraine.}

G. squarrosa has been known in cultivation in Ukraine since 1942, which is confirmed by herbarium specimens collected by E. T. Polonska (July 24, 1942, KW, s.n.) at the site of the section of new crops of the Botanical Garden in Kiev (now the M. M. Gryshko National Botanical Garden, NAS of Ukraine), named Inula sp. Another centre of cultivation of the species before the Second World War was probably the nursery of medicinal plants at Pavlov field in Kharkiv, but precise data about this are absent (Protopopova 1973). One more cultivation centre was the Nikita Botanical Garden in Crimea. The plants grew there in the collection of technical and medicinal plants. However, we assume that the first locations of spontaneous introduction of G. squarrosa in Ukraine were not botanical gardens, but the ports of Berdyansk and Mykolaiv. During World War II, hay was imported into these military ports from the United States, for horse feed. From here the species spread northwards by railway. Subsequently, a third centre arose near the river crossing in the vicinity the village of Slovianoserbsk (Luhansk Region), where the same trains were located. This conclusion is made on the basis of analysis of the first locations of the species.

The first period (70-ies of XX century) of spontaneous distribution of the species on the territory of Ukraine was summarized in the work of Protopopova (1973). G. squarrosa was discovered for the first time in 1949 on pastures near the railway and on disturbed steppe grasslands in the south-eastern part of the Mykolaiv Region (between Yavkyne and Nova Poltavka stations of Bashtanka and Novyi Bug Districts) (Bilyk 1950). From here, the spe- 
cies spread to the Nova Odesa, Voznesensk and Pervomaisk Districts in the same region and to the Lymanskyi (former Kominternovskyi) District of the Odesa Region, and then to Moldova (Myrza 1987). A second locality was found in the Azov Region in the port of Berdyansk, in the Zaporizhzhia Region, from where the species spread by railway to Novomlynivka Kuibyshevsky (now Bilmatskyi) District of the same region. A third locality was found in the floodplain of the Siverskyi Donets river (Bilyk \& Tkachenko 1963, 1977, Kucher 2012, 2015). Subsequently, new localities were recorded in Donetsk (Bilyk \& Tkachenko 1963, 1977), Kharkiv (Protopopova 1973) and Cherkasy Regions (Bilyk 1969). The plants were distributed mainly in western, northwest and north directions by railways and roads from all the aforementioned centres, with plants only being recorded along to the wayside of these pathways. At the same time, existing populations were expanding. In an easterly direction, only two localities were found along the railways - the village of Vyshneve (former Erastivka) of Pyatykhatsky
District, Dnipropetrovsk Region (Larionov 1950, $K W$ ) and station Bobrynets Kirovohrad (now Kropyvnytskyi) Region. Thus, in the late 1970's three main centres were formed in different botanical and geographical regions of the Steppe zone (Right-bank, Left-bank and Starobilsky grassland-meadow steppe). These localities are considerably remote from each other and located in such a way that it provides expansion of G. squarrosa to the south and southeast of the country. The small location that formed in Crimea is quite localized. In the 1970's, G. squarrosa consolidated its area in the south (Mykolaiv, Kherson and Odesa Regions) and in the east (Luhansk and Donetsk Regions) of the Steppe zone of Ukraine. It seems that $G$. squarrosa, as a salt-tolerant plant, has advantages over many native plant species. There are new localities of the species on the railways up to Kyiv (1977). At the end of the 1970's, the species was recorded in 11 (44\%) administrative regions of Ukraine, i.e., also outside the Steppe zone of Ukraine.

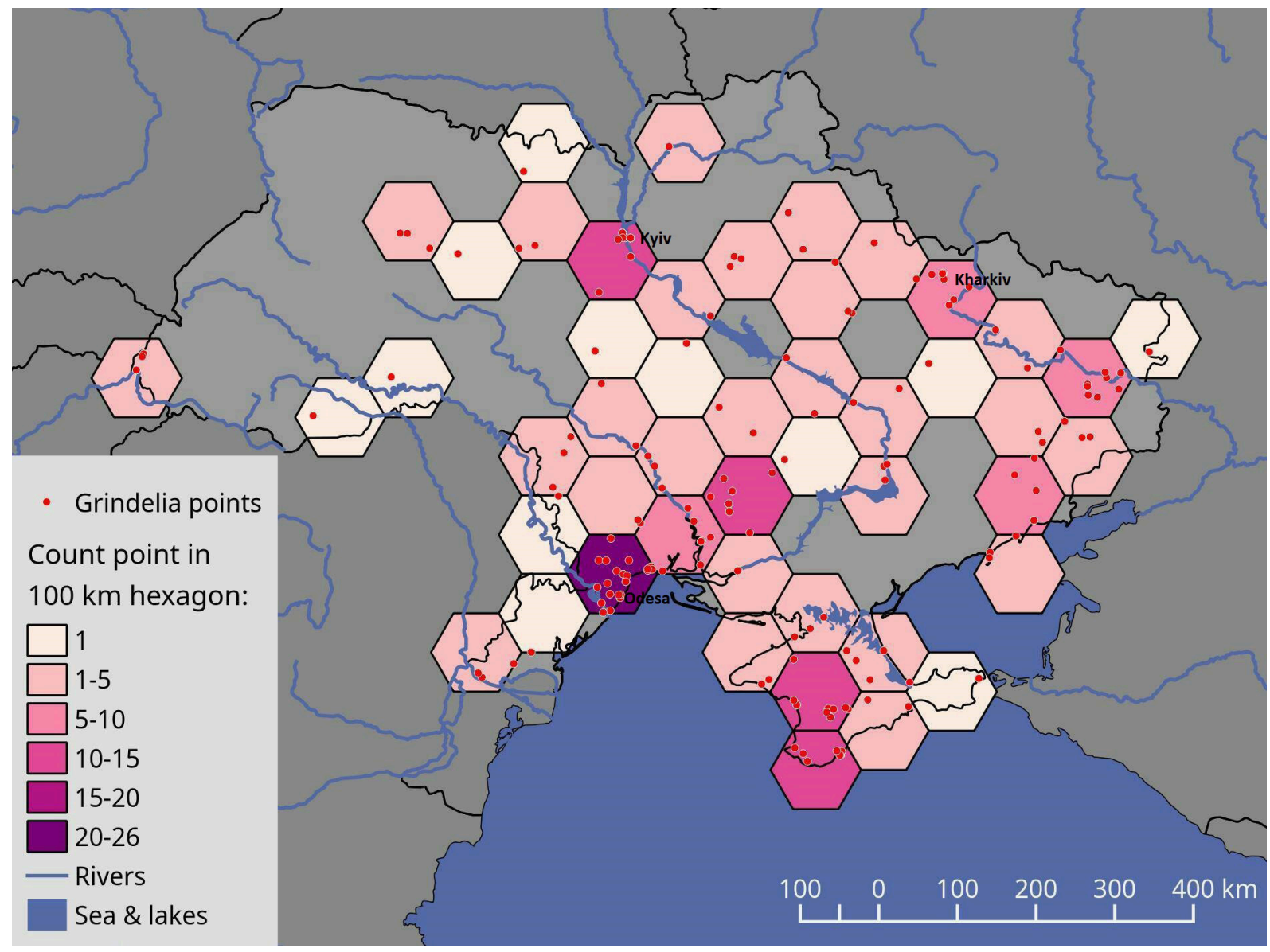

Figure 1: Map of distribution Grindelia squarrosa in Ukraine.

Slika 1: Razširjenost vrste Grindelia squarrosa v Ukrajini. 
From 1970-1980, the number of localities of G. squarrosa in Ukraine almost doubled. Outbreaks of expansion were reported in the Steppe zone. In the 1980s, a new location of the species was discovered in Rivne Region (Ostroh).

In the 1990s, G. squarrosa totally naturalized in the south and east of Ukraine, where the species became one of the most noticeable alien plants. There were also new finds near the railways in Transcarpathia (Uzhhorod), Poltava and Vinnytsia Regions and places not connected with the railways - Kyiv (Bila Tserkva), as well as Cherkasy (Kozyn and Hryhorivka villages of Kaniv Districts) Regions.

In the 2000s, new locations were recorded in the Forest-Steppe and Forest zones of Ukraine: in Poltava (Poltava and Pyriatyn) (Kovalenko 2011), Transcarpathia (Chop), Chernivtsi (Chorney et al. 2010; Sytchak 2015), Rivne (Gutsman \& Gutsman 2014), Khmelnytskyi (Shepetivka, Netishyn), Zhytomyr (Zhytomyr, Olevsk and Korostyshiv districts), Chernihiv (Chernihiv), Sumy (Hlukhiv) Regions and in the Crimea. In recent years, new recordings have been documented in north-western districts, in particular in the Lviv Region, in 2015 and 2018 noted on railway tracks in Brody and its environs, and railway stations Zolochiv, Krasne and Ozhidiv (Batochenko \& Yurechko 2019).

During the 70 years since the species was recorded in Ukraine for the first time, G. squarrosa has been significantly expanding its presence in the Steppe and ForestSteppe zones of Ukraine and formed island localities in the Polissia (Forest zone of Ukraine) and Western Podillia natural regions. Throughout this period, the trend of species dispersion in western, north-western and northern directions has continued and today, more than 300 localities are already known. In the past 20 years, 92 new localities have been recorded (Figure 1, Figure 2).

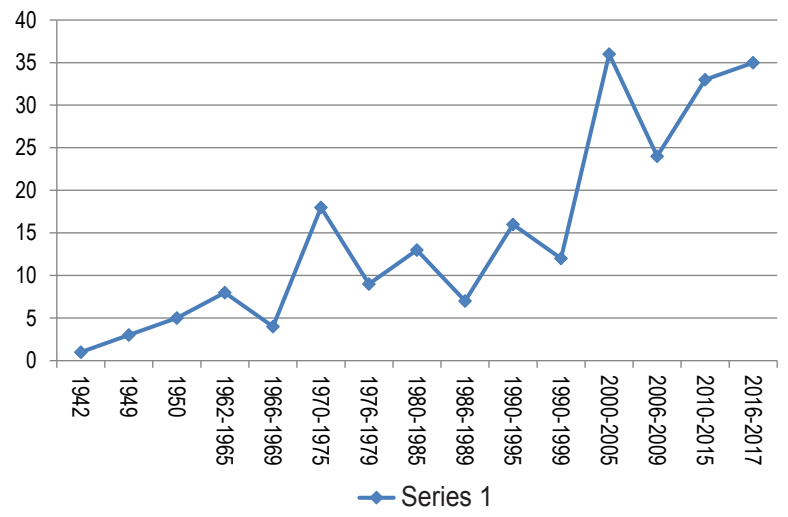

Figure 2: Number of new localities Grindelia squarrosa in Ukraine. Slika 2: Število novih lokacij vrste Grindelia squarrosa v Ukrajini.

\section{Ecology and syntaxonomy of $G$. squarrosa in Ukraine}

In Ukraine, G. squarrosa is a hemicryptophyte, in relation to the water regime it is a xeromesophyte and in relation to the light it is a heliophyte. The species has wide ecological amplitude and occurs in various synanthropic and some natural habitats. Plants occur mainly in anthropogenic habitats: railway embankments, roadsides, windbreaks, pastures, quarries, rocky scree, sandy wastelands, fallows, clay and sandy river banks etc., as well as in seminatural and natural habitats: degraded sandy or rocky steppes, steppe slopes, granite outcrops, wood glades and forest edges. In other words, they are linked to sites of reduced coenotic competition.

The species reproduces in a generative way, the seeds are propagated both anthropochorically and by zoo- and hydrochoric means (Klymenko \& Men'shova 2012). According to our estimates, the average number of seeds of one inflorescence is 187 pcs. (i.e., 1870 seeds from one plant) (Kucher 2012, 2020). The seed productivity is 7-25,000 per plant (Burda et al. 2015) and can be a maximum of 260,000 seeds per plant (Protopopova \& Shevera 2010).

Plants quickly form a nucleus in anthropogenically transformed areas. From there, the plants penetrate neighbouring plant communities weakened by anthropogenic pressure or areas with sparse vegetation, undeveloped (on fallows) or disturbed (on pastures) steppe communities, thereby overcoming the phytocoenotic barrier. $G$. squarrosa takes root even in places where species of Stipa spp., Festuca valesiaca and some other steppe species are present. This slows down the regeneration of natural vegetation. In addition, colonies and clumps of species contribute to the native population's insularization. This in turn leads to depression, causes a redistribution of species according to their role in the communities and thus changes the structure of natural cenoses. G. squarrosa is thus a transformer in the southern regions of the Steppe zone. As a result, new plant communities are formed, reaching the syntaxonomic level of associations. In general, the species is recorded in communities of five vegetation classes (see syntaxonomic scheme).

G. squarrosa is recorded in E and I type of biotypes in the territory of many protected areas of Ukraine, e.g., Dunayskyi and Chornomorskyi Biosphere Reserves, Dniprovsko-Orilskyi, Kazantypskyi, Crimean, Mys Martyan, Ukrainian Steppe Nature Reserves, Buzkyi Gard, Vyzhnytskyi, Dvorichanskyi, Karmelyukove Podillya, Pyryatynskyi, Sviaty Hory, Khotynskyi National Nature Parks, and this poses a significant threat to natural communities (Burda et al. 2015, Zavyalova 2017). 


\section{Syntaxonomic scheme}

\section{Artemisietea vulgaris Lohmeyer et al. in Tx. ex von Rochow 1951}

Agropyretalia intermedio-repentis T. Müller et Görs 1969

Convolvulo arvensis-Agropyrion repentis Görs 1967

Convolvulo-Agropyretum repentis Felföldy 1943

Calamagrostietum epigeios Kostylev in V. Solomakha et al. 1992

Onopordetalia acanthii Br.-Bl. et Tx. ex Klika et Hadač 1944

Onopordion acanthii Br.-Bl. et al. 1936

Lappulo squarrosa-Grindelietum squarrosae Smetana 2002 nom. inval.

Ambrosio artemisiifoliae-Grindelietum squarrosae Smetana 2002 nom. inval.

Achilleo submillefolii-Gypsophiletum perfoliatae Smetana, Derpoluk, Krasava 1997 nom. inval.

Dauco-Melilotion Görs ex Rostański et Gutte 1971 Melilotetum albi-officinalis-Grindelietosum squarrosae Smetana 2002 nom. inval.

\section{Sisymbrietea Gutte et Hilbig 1975}

Sisymbrietalia sophiae J. Tx. ex Görs 1966 nom. conserv. propos.

Sisymbrion officinalis Tx. et al. ex von Rochow 1951 Ivaetum xanthiifoliae Fijałkowski 1967

\section{Robinietea Jurko ex Hadač et Sofron 1980}

Chelidonio-Robinietalia pseudoacaciae Jurko ex Hadač et Sofron 1980

Chelidonio-Acerion negundo L. Ishbirdina et A. Ishbirdin 1989

Crambo-ponticae-Rhusetum typhinae Smetana 2002 Chelidonio-Aceretum negundi L. Ishbirdina et A. Ishbirdin 1989

\section{Festuco-Brometea Br.-B1. et Tx. ex Soó 1947}

Festucetalia valesiacae Soó 1947

Festucion valesiacae Klika 1931 nom. conserv. propos. Festuco valesiacae-Koelerietum cristatae Smetana, Derpoluk, Krasova 1997 nom. inval.

Cluster analysis of geobotanical relevés using the JUICE program showed that plants of the species $G$. squarrosa most often occurred in ruderal communities of the class Artemisietea vulgaris and semi-natural communities of the class Festuco-Brometea.

The mean values occupying the area in mid-point are characteristic of such edaphic factors as salt regime $(\mathrm{Sl})$ - eutrophic subglycotroph, growing on saline-enriched $\left(\mathrm{HCO}_{3}\right)$ soils, nitrogen content $(\mathrm{Nt})$ - heminitrophil-ni- trophil with an average and sufficiently depleted content of mineral nitrogen compounds in the soil. This causes spread on many types of substrates with varied chemical compositions, from loamy to sandy soils. Optimal indicators of carbonate $(\mathrm{Ca})$ - acarbonate-hemicarbonatephiles; acidity $(\mathrm{Rc})$ and variability of moisture $(\mathrm{Fh})$ are at the level of scale values of $60 \%$, and the maximum reaches or does not exceed $70 \%$, which limits its distribution, i.e., it can withstand a small content of carbonates (Figure 3).

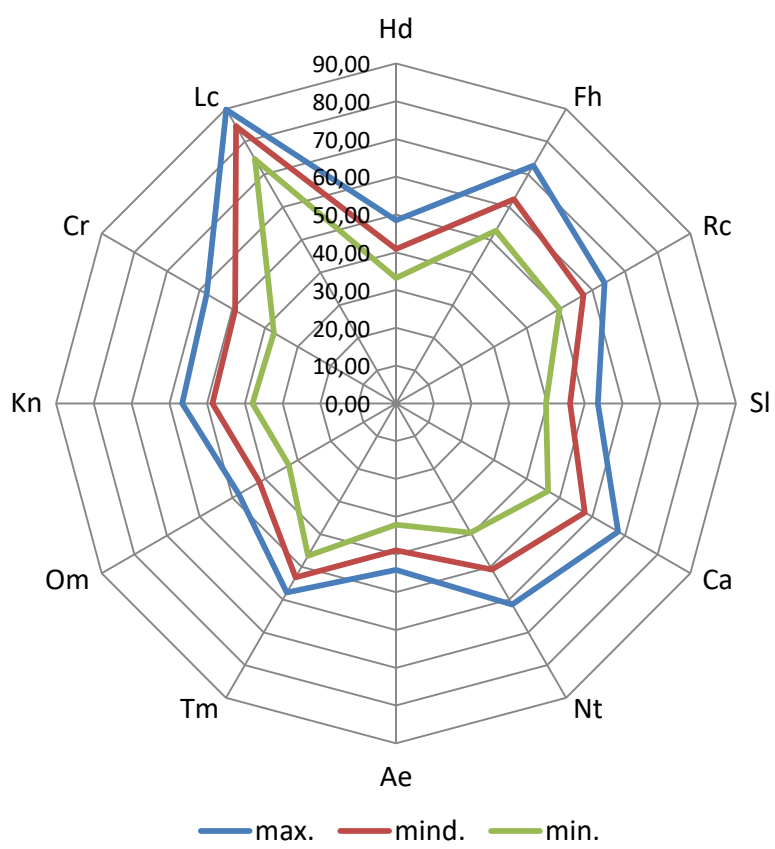

Figure 3: Cyclogram of amplitudes of ecofactor indicators (abbreviations are given in the text).

Slika 3: Krožni graf razpona ekoloških indikatorjev (okrajšave so podane v besedilu).

Indicators of light in the community (Lc) reach maximum values (heliophyte). However, the amplitude of fluctuations in this indicator is one of the widest. That is to say, the species tends to open areas with diffused light.

Pursuant to climatic indicators of thermal climate ( $\mathrm{Tm})$, this species is a submesotherm $\left(1675 \mathrm{MJ} / \mathrm{m}^{2}\right)$, of cryoclimate $(\mathrm{Cr})$ - it is sub-cryophyte, growing at winter temperatures down to $-10{ }^{\circ} \mathrm{C}$, of continentality $(\mathrm{Kn})$ - hemicontinental $(30 \%)$, the mean values occupying the area in mid-point (40-60\%). While the humidity value $(\mathrm{Om})$ is below the optimum (30-50\%) - meso-aridophyles, i.e, the species grows when the amount of evaporation exceeds the amount of precipitation. According to these ecological indicators, the optimum of the species is in the Steppe zone.

A characteristic feature of all scales is that the amplitude towards the minimum is wider than the mean values of maximum. 
DCA ordination data showed that the most distinct values of the main environmental factors were characteristic of the association Lappulo squarrosae-Grindelietum squarrosae. However, the values of ecofactors for communities of the class Festuco-Brometea and other communities of the class Artemisietea vulgaris are quite similar (Figure 4).

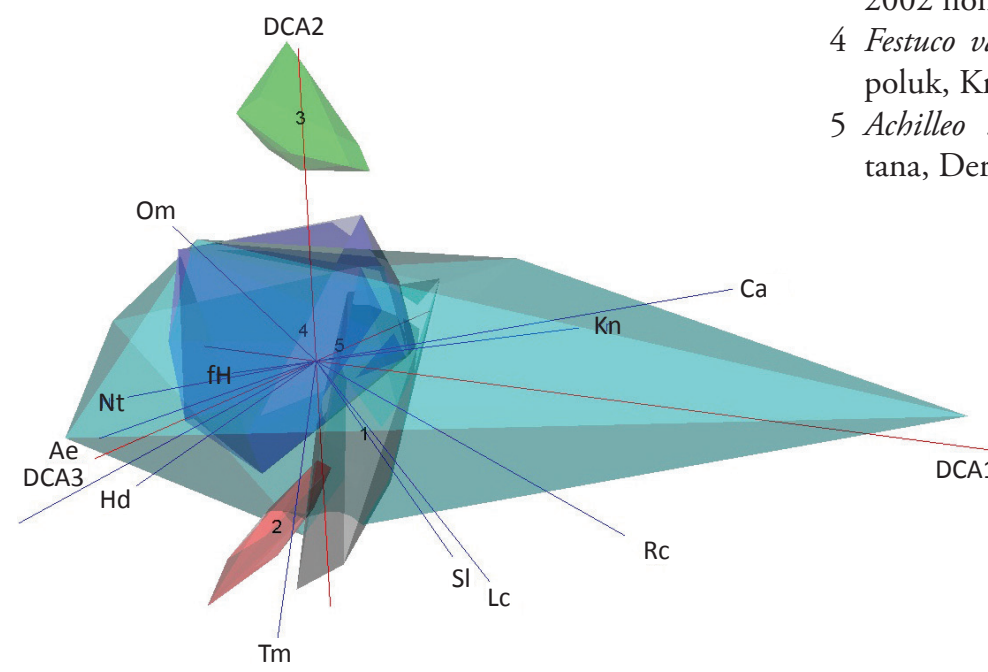

Figure 4: DCA ordination of major associations with Grindelia squarrosa in Ukraine. Slika 4: DCA ordinacija glavnih asociacij z vrsto Grindelia squarrosa v Ukrajini.

\section{Explanation:}

1 Melilotetum albi-offcinalis-Grindelietosum squarrosae Smetana 2002 nom. inval.

2 Ambrosio artemisiifoliae-Grindelietum squarrosae Smetana 2002 nom. inval.

3 Lappulo squarrosa-Grindelietum squarrosae Smetana 2002 nom. inval.

Festuco valesiacae-Koelerietum cristatae Smetana, Derpoluk, Krasova 1997 nom. inval.

Achilleo submillefolii-Gypsophiletum perfoliatae Smeana, Derpoluk, Krasava 1997 nom. inval.

Using the Statistica program, a dendrogram of the distance of the relevés from the most optimal environmental indicators was constructed. The resulting clusters do not reflect the syntaxonomic structure of the communities: pioneer communities of the class Artemisietea vulgaris occupy the extreme pole positions, and the more developed communities of the Festucion valesiacae alliance are located in the centre of the dendrogram (Figure 5). We discovered that the optimum conditions were characteristic of communities with the participation of Grindelia squarrosa that were found

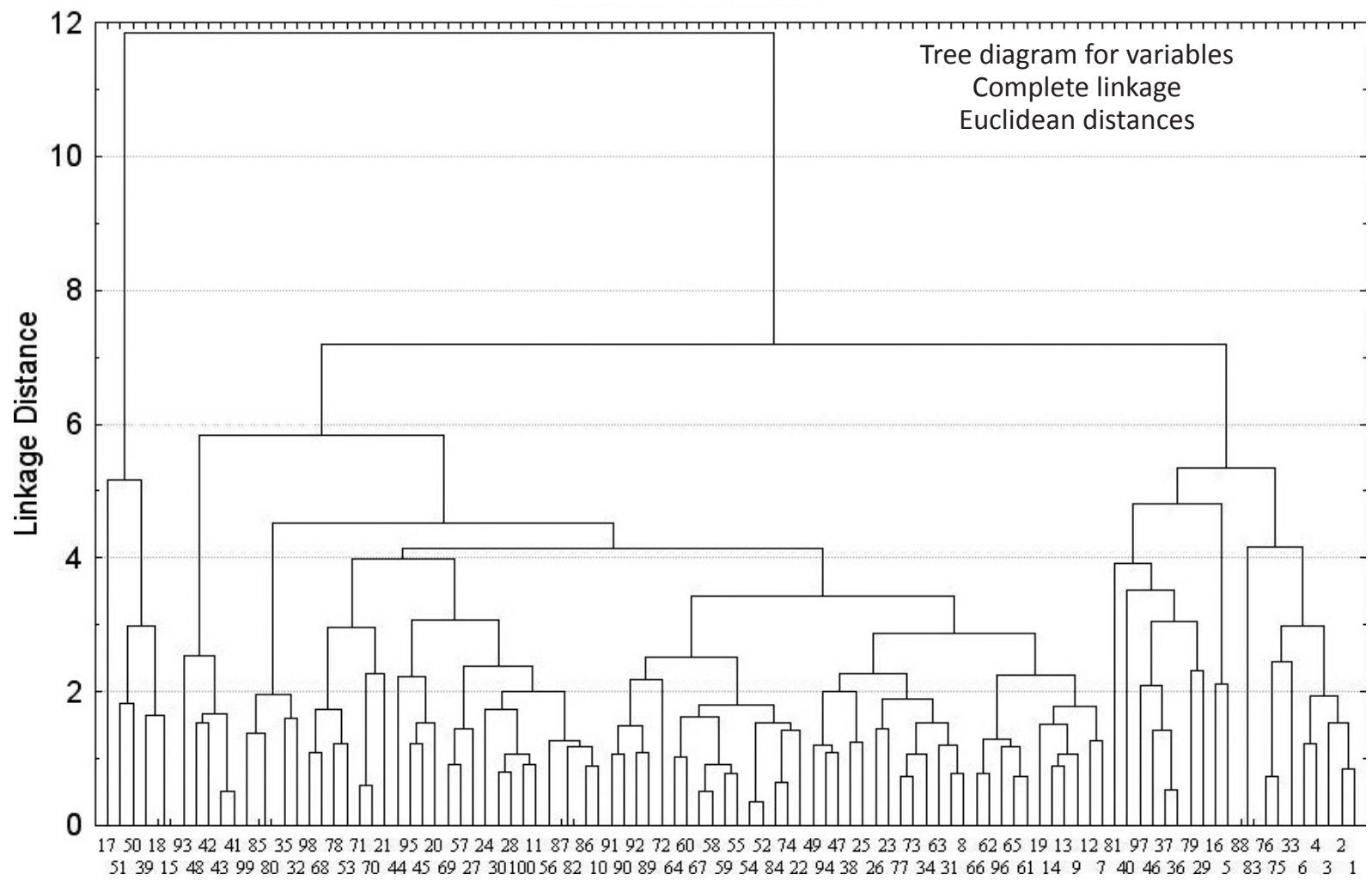

Figure 5: Dendrogram that reflects the distance of the relevés from the optimal conditions.

Slika 5: Dendrogram s prikazom razlike med vegetacijskimi popisi in optimalnimi razmerami. 
near Kreminna, Luhansk Region (data of the authors), in the south of Kirovohrad Region (data of E. V. Polyovyj), and on old dumps of Kryvyi Rih, where succession processes are already taking place (data of M. G. Smetana).

The most distant from the optimal values were the relevés of railway verges in Chernivtsi Region (data of I. I. Chorney and A. I. Tokaryuk) and overgrown sludge dumps created in Kryvyi Rih (data of M. G. Smetana).

\section{Conclusions}

G. squarrosa is thus characterized in the secondary range in Ukraine, by high levels of seed productivity and germination, variable modes of dispersal, and wide ecological and coenotic amplitudes and CSR-strategy.

The modern distribution of the species in Ukraine demonstrates a tendency to expansion in northern and western directions, which is probably due to climatogenic changes.

Based on a comprehensive analysis of the data and obtained results, it can be concluded that at the beginning of naturalization, G. squarrosa seeds fell into anthropogenically disturbed habitats (Cl. Artemisietea vulgaris). In these communities, the conditions deviated from the optimal for the species towards a greater continentality, higher thermal regime and lower soil humidity. Further naturalization took place in the direction of optimum conditions (Cl. Festuco-Brometea), and expansion of the area of the species in northern and western directions.

In the future, it can be predicted that, due to the potential ability of the species to adapt and under the influence of climate change, there is a higher probability that the species will spread in northern and western directions. The conditions for such a spread are disturbed meadowsteppe fringe xeromesic communities with reduced coenotic competition. The presence of invasive species additionally contributes to Grindelia squarrosa spreading into semi-natural communities.

\section{Acknowledgments}

We would like to thank the curators and staff of the mentioned Herbariums, Prof. Dr. I. I. Chorney and Dr. A. I. Tokaryuk (Yu. Fedkovych Chernivtsi National University), Dr. A. A. Kuzemko, Dr. D. A. Davydov and E. V. Polyovyj (M. G. Kholodny Institute of Botany, NAS of Ukraine), Mgr. N. Bessarab for their valuable help and advice, and assistance in improving the style and language of the manuscript. We are grateful to the anonymous reviewers and editor-in-chief Urban Šilc for their valuable comments on the manuscript.

\section{Zavialova (D) https://orcid.org/0000-0003-4160-1083 \\ Ya. P. Didukh (D) https://orcid.org/0000-0002-5661-3944 \\ Vira V. Protopopova (D) https://orcid.org/0000-0002-1492-1084 \\ Myrosval V. Shevera (D) https://orcid.org/0000-0002-1178-0458 \\ Oksana O. Kucher (D) https://orcid.org/0000-0002-5665-288X}

\section{References}

Anastasiu, P. \& Negrean, G. 2005: Alien plants in Romania. Analelestiintifice ale Universitatii “Al. I Cuza” Iasi Tomul LI, s II a Bilogie Vegetala: 87-96 p.

Balogh, L., Dancza, I. \& Királ Y. G. 2004: Actual list of neophytes in Hungary and their classification according to their success. In: Mihály, B. - Botta-Dukát, Z. (eds.), Biological invasions in Hungary, Invasive plants. pp. 61-92.

Bartoli, A. \& Tortosa, R. D. 2012: Revision of the North American species of Grindelia (Asteraceae). Annals of the Missouri Botanical Garden 98: 447-513. DOI: https://doi.org/10.3417/2008215

Batochenko, V. M. \& Yurechko, R. Yu. 2019: Alien species in the West of Podillya. News Biosphere Reserve "Askania-Nova" (100 years of state protection in Ukraine: results and prospects (International Scientific Conference, April 23-25, 2019). Special. Issue, 21: 423-425. [In Ukrainian].

Braun-Blanquet, J. 1964: Pflanzensoziologie. Grundzüge der Vegetationskunde. Springer Verlag, 865 p.

Botta-Dukát, Z. 2008: Invasion of alien species to Hungarian (semi-) natural habitats. Acta Botanica Hungarica 50 (Suppl.): 219-227.

Bilyk, G. I. 1950: New alien plant for the Ukrainian SSR floraGrindelia squarrosa (Pursh) Dunal. Botanical Journal of Academy of Sciences of the USSR 27 (7): 76-79 [In Ukrainian].

Bilyk, G. I. \& Tkachenko, V. S. 1963: Grindelia squarrosa (Pursh) Dun. in the flood plain of the Siversky Donets. Ukrainian Botanical Journal 20(4): 16-21 [In Ukrainian].

Bilyk, G. I. \& Tkachenko, V. S. 1977: New location of Grindelia squarrosa (Pursh) Dunal in Ukraine. Ukrainian Botanical Journal 34 (1): 92-93 [In Ukrainian].

Burda, R. I., Pashkevych, N. A., Boiko, G. V. \& Fitsailo, T. V. 2015: Alien species of the protect foras of Forest-Steppe of Ukraine. Kyiv: Naukova dumka, 219 p.

Chorney, I., Tokaryuk, A. \& Budzhak, V. 2010: Grindelia squarrosa (Pursh) Dunal (Asteraceae), a new alien species in the flora of Chernivtsi region. Anthropization and Environment of Rural Settlements. Flora and Vegetation: IX International Conference (Kamyanets-Podilskiy \& Boyany, Ukraine, 29 Jun.-01 Jul. 2010): Program, Proceedings and Excursion. - Kyiv: M. G. Kholodny Institute of Botany, NAS of Ukraine, P. 22.

Didukh, Ya. P. 2011: The ecological scales for the species Ukrainian flora and their use in synphytoindication. Kyiv: Phytosociocentre, 176 p.

Didukh,Ya. P. \& Pliuta, P. G. 1994: The phytoindication of ecological factors. Kyiv, Naukova Dumka, 280 p.

Dubyna, D. V., Dziuba, T. P., Iemelianova, S. M., Bagrikova, N. O., Borysova, O. V., Borsukevych, L. M., Vynokurov, D. S., Gapon, S. V., Gapon, Y. V., Davydov, D. A., Dvoretsky, T. V., Didukh, Y. P., Zhmud, 
O. I., Kozyr, M. S., Konyschuk, V. V., Kuzemko, A. A., Paskevych, N. A., Ryff, L. E., Solomakha, V. A., Felbaba-Klushyna, L. M., Fitsailo, T. V., Chorna, G. A., Chorney, I. I., Shelyag-Sosonko, Y. R., \& Iakushenko, D. M. 2019: Prodrome of the vegetation of Ukraine. Naukova Dumka, Kyiv, 782 p. [In Ukrainian].

Flora of the Baltic countries. III. 2003: compendium of vascular plants [Campanulaceae-Orchidaceae]. Tartu. Vol. 3, 406 p. [In Russian].

Flora of the European part of the USSR, Vol. VII, 1994: Sankt Peterburg: Nauka, 317 p.

Gabrielian, E. Tz., Timukhin, I. N., Tuniyev, B. S. \& Aghababyan, M. V. 2016: A new invasive genus Grindelia (Asteraceae) from Armenia and new locations in NW and W Transcaucasia. Takhtajania, 130-132 [In Russian].

Gleason, H. A. \& Cronquist, A. 1991: Manual of vascular plants of northeastern United States and adjacent. 2nd ed. New York: New York Botanical Garden, 910 p.

Greuter, W. 2005-2007: The Euro+Med Plant base. Cited 20 Oct. 2006

Gudžinskas, Z. 1997: Conspectus of alien plant species of Lithuania. 4. Asteraceae. Botanica Lithuanica,3(4): 335-366.

Gutsman, S. V. \& Gutsman, M. V. 2014: Alien fraction of the flora of Rivne city. Scientific issues Ternopil Volodymyr Hnatiuk National Pedagogical University. Series Biology, 4(61): 28-32 [In Ukrainian].

Ignatov, M. S. \& Makarov, V. V. 1984: Grindelia squarrosa (Compositae) is a new species for the flora of the North Caucasus. Bulletin of Moscow Society of Naturalists. Biological series,93(4): 106 [In Russian].

DAISIE 2009: Handbook of Alien Species in Europe. Springer, p. 399.

Hansen A., 1976: Grindelia Willd. In: Tutin T. G. (ed), Flora Europaea, vol 4, Plantaginaceae to Compositae (and Rubiaceae). Cambridge: Cambridge University Press, pp 505.

Jehlik, V., Majekova, J. \& Zaliberova, M. 2013: New discovered adventive plants from eastern Slovakia. Thaiszia. 23 (1): 61-66.

Jinjolia, L. \& Shakarishvili, N. 2014: Grindelia squarrosa (Pursh) Dunal - a New Alien Genus and Species for Flora of Georgia. Bulletin of Georgia Nat. Acad. Sci. 8(3): 64-68.

Klymenko, O. L. \& Men'shova, V. O. 2012: Specifics of ontogenesis of species of genus Grindelia Willd. Plant introduction, 4: 48-52 [In Ukrainian].

Kovalenko, O. A. 2011. Invasion of Grindelia squarrosa (Pursch.) Dun. (Asteraceae) in the vicinity of NPP Pyriatynsky (Poltava region). Youth and progress of biology: collection of abstracts of VII International science conference of students and graduate students (April 5-8, 2011, Lviv), 99-100 [In Ukrainian].

Kozhevnikov, A. E. \& Kozhevnikova, Z. V. 2007: Flora of the Amur River Basin (Russian Far East). Taxonomic Diversity and Spatial Changes in Taxonomic Structure. Komarov Readings Vol. LV: 104-183 [In Russian].

Kucher, O. O. 2012: An invasive species of Grindelia squrrosa (Pursh) Dunal. on the territory of eastern Ukraine. In: Zagorodniuk, I. V. (ed.). the collection of works: Dynamics of biodiversity 2012 / Ed. Lugansk: Taras Shevchenko Lugansk National University, pp. 96-99. [In Ukrainian].
Kucher, O. O. 2015: Transformer species in the flora of Starobilsk grass-meadow steppe (Ukraine). Boiodiversity: Research and Conservation 40: 49-58.

Kukk, T. 1999: Eestitaimestik. Teaduste Akadeemia Kirjastus, TartuTallinn. pp. 464.

Kurtto, A. 2020: FinBIF, https://laji.fi/en/observation/finnish?target= MX.41107 (Accessed: 15.9.2020)

Proffesional User's Guide Version 7.0. 2002: MapInfo Corporation Troy, New York: 759 p.

Mucina, L., Bueltmann, H., Dierßen, K., Theurillat, J.-P., Raus, T., Čarni, A., Šumberová, K., Willner, W., Dengler, J., Gavilán, R., Chytrý, M., Hájek, M., Di Pietro, R., Iakushenko, D., Pallas, J., Daniëls, F., Bergmeier, E., Santos Guerra, A., Ermakov, N. \& Tichý, L. 2016: Vegetation of Europe: Hierarchical floristic classification system of vascular plant, bryophyte, lichen, and algal communities. Applied Vegetation Science 19 (Suppl. 1): 3-264. DOI: https://doi. org/10.1111/avsc. 12257

Myrza, M., Kuharskaya, L. \& Gohu, D. 1987: Distribution of Grindelia squarrosa (Pursch.) Dun. on the territory of Moldova. Ukrainian Botanical Journal 44 (6): 42-44 [In Russian].

Natkevičaitè, M. 1951: Lietuvos TSR adventyvinè flora. Lietuvos TSR Mokslų Akademijos Biologijos instituto darbai, 1: 77-124

Neupane, B. P. 2017: Biofuels and Biomaterials from an Arid Lands Plant, Grindelia squarrosa A dissertation submitted in partial fulfillment of there quirements for the degree of Doctor of Philosophy in Environmental Sciences University of Nevada, Reno: 160.

Polovyj, E. V. 2013: Ecological features of Grindelia squarrosaas invasive species on the territory of Savranka river basin. In: Proceedings of the Conference: Actual problems of botany and ecology, Scholkine, $180-181 \mathrm{p}$.

Protopopova, V. V. 1973: Alien plants of the forest steppe and steppe of Ukraine. Kyiv: Naukova Dumka, 192 p. [In Ukrainian].

Protopopova, V. V. 1991: The synanthropic flora of Ukraine and the ways of its development. Kiev, Naukova Dumka, 201 p. [In Russian].

Protopopova, V. V., Tkachenko, V. S. 1979: History and propagation of Grindelia squarrosa (Pursh) Dunal. Ukrainian Botanical Journal 36 (5): 457-461. [In Ukrainian].

Protopopova, V. V., Mosyakin, S. L. \& Shevera, M. V. 2002: Plant invasions in Ukraine as a threat to biodiversity: the present situation and tasks for the future. Kyiv, Institute for Botany M. G. Kholodnyi of the National Academy of Sciences of Ukraine, 28 p. [In Ukrainian]

Protopopova, V. \& Shevera, M. 2010: Grindelia squarrosa (Pursh) Dunal as an invader of steppe communities in Ukraine. NEOBIOTA 2010. Biological invasions in a changing world from science to management. Abstract book. (Copenhagen, 14-17 September 2010). Copenhagen, 2010, p. 114.

Protopopova, V. V. \& Shevera, M. V. 2019: Invasive species in the flora of Ukraine. I. The group of highly active species. GEO\&BIO 17: 116-135. [In Ukrainian].

Protopopova, V. V., Shevera, M. V., Mosyakin, S. L., Solomakha, V. A., Solomacha T. D., Vasiliyeva, T. V. \& Petrik, S. P. 2009: Invasion plants in the flora of the Northern Black Sea Coast. Kyiv, Phytosociocenter, 56 p. [In Ukrainian]. 
Peterson, J. G. 1970: The food habits and summer distribution of juvenile sage grouse in central Montana. Journal of Wildlife Management. 34 (1): 147-155. DOI: https://doi.org/10.2307/3799502

Puzyrev, A. N. 1985: Addition to the alien flora of Udmurtia. Botanical Journal 70 (2): 268-271 [In Russian].

Reynolds, S. C. P. 2002: A catalogue of alien plants in Ireland. Glasnein, National Botanic Gardens, Occasional Papers.14, 41 p.

Sieg, C. H. Uresk, D. W \& Hansen, R. M. 1983: Plant-soil relationships on bentonite mine spoils and sagebrush-grassland in the northern High Plains. Journal of Range Management 36 (3): 289-294.

Sîrbu, C \& Oprea, A. 2008: Two alien species in the spreading process in Romania: Reynoutria x bohemica Chrtek et Chrtková, and Grindelia squarrosa (Pursh) Dunal. Agronomical Research in Moldavia 41: 41-50.

Shevera, M., Kucher, O., Zavialova, L., Nowak, T., Bzdenga, K., Zarychta, A. \& Tokarska-Guzik, B. 2019: Grindelia squarrosaeconomic useful or invasive species in Europe. Integrating research, management and policy. In: P. Pyšek, J. Pergl \& D. Moodley (eds.), Book of abstracts of the 15 EMAPI Conference (9-13 Sept. 2019, Prague, Czech Republic). Průhonice: Institute of Botany, Czech Academy of Sciences, p. 183.

Smetana, M. G. 2002: Syntaxonomy of steppe and ruderal vegetation of Kryvyi Rih. Kryvyi Rih: Publishing house "IVI”, 132 p. [In Ukrainian].

Solomakha, V. A., Kostylev O. V. \& Shelyag-Sosonko, Yu. R. 1992: Synanthropic vegetation of Ukraine. Kyiv, Naukova Dumka, 252 p. [In Ukrainian].

StatSoft, Inc. 2005: STATISTICA (data, analysis, software system) Version 10.0, http://www.statsoft.com.

Strother, J. L. \& Wetter, M. A. 2006: Grindelia. In Flora of North America Editorial Committee, editors. Flora of North America North of Mexico: Vol. 20: Magnoliophyta: Asteridae, part 7: Asteraceae, part 2. New York: Oxford, P. 424-436.
Steyermark, J. A., 1937: Studies in Grindelia. III. Annals of the Missouri Botanical Garden 24 (2): 225-262.

Sytchak, N. M. 2015: Additions to the flora of vascular plants of NNP "Vizhnitsky", Chernivtsi Region. Scientific Herald of Chernivtsi University. Biology (Biological Systems) 7(2): 244-248. [In Ukrainian].

Tretyakov, D. I. 1990: New and rare species of vascular plants for the flora of Belarus. Botanical Journal 75(2):255-266 [In Russian].

Truta, E., Vochita, G., Oprea, A. \& Sibru, C. 2012: Karyotype traits in Grindelia squarrosa (Pursh) Dunal (Asteraceae), an invasive plant in Romania Silvae Genetica 61 (4-5):179-185.

Tokarska-Guzik, B., Bzdęga, K., Nowak, T., Urbisz A., Węgrzynek, B., Dajdok, Z. 2015: Propozycja listy roślin gatunków obcych, które mogą stanowić zagrożenie dla przyrody Polskii Unii Europejskiej Katowice: 178 p.

Tichý, L. 2002: JUICE, software for vegetation classification. Journal of Vegetation Science 13: 451-453. DOI: https://doi. org/10.1111/j.1654-1103.2002.tb02069.x

Verloove, F. 2006: Catalogue of neophytes in Belgium (1800-2005) Scripta Botanica Belgica, vol. 39: 1-89.

Vladimirov, V. \& Petrova, A. S. 2012: Grindelia squarrosa: a new alien species for the Bulgarian flora. Phytologica Balcanica 18 (3): 315-318.

Vynokurov, D. S. 2014: Syntaxonomy of xerothermic vegetation of the Ingul River valley (Class Festuco-Brometea). Part 1. PetrophyttoSteppe vegetation. Ukrainian Botanical Journal 71(2): 148-160 [In Ukrainian].

Zavialova, L. V. 2017: The most harmful invasive plant species for native phytodiversity of protected areas of Ukraine. Scientific Herald of Chernivtsy University. Biology (Biological Systems), 9 (1): 87-107 [In Ukrainian]. 